1(1)(2021) 97-102

Journal homepage: https://ojs.unikom.ac.id/index.php/injuratech

\title{
Information Technology for Consumer Interest Withdrawal
}

\author{
T Rohmawati ${ }^{*}$, J Rahmayanti ${ }^{2}$ \\ 1Departemen Ilmu Pemerintahan, Universitas Komputer Indonesia, Indonesia \\ 2Departemen Ilmu Komunikasi, Universitas Komputer Indonesia, Indonesia \\ Email: *tatik.rohmawati@email.unikom.ac.id
}

\begin{abstract}
The purpose of this study is to determine the impact of social media content as a Consumer Interest Withdrawal Strategy. The method used in this study is a qualitative method by collecting data descriptively, namely by analyzing several online shops on the Instagram application. The results show that social media is used to buy products from the online shop. Online shop owners do not need to use a lot of money to arrange content on Instagram because it only requires creativity to make it more attractive, namely with themes, colors, and the preparation of content that is consistent. In conclusion, the development of technology provides a place for business people to start and continue business from marketing, promotion, to making consumers have a more efficient interest.
\end{abstract}

\section{Introduction}

The development of communication and information technology is something that cannot be avoided nowadays. Business people are using technology, especially the internet, as a promotional medium to attract consumers. In increasing shopping trends, online businesses see online trends, which implemented to e-commerce systems [1]. This encourages them to compete and provide innovation to get more consumers. Social media is a medium to make it easy to spread and promote their products without having to meet in person. Instagram is a social media that has great potentials to start, spread, and promote a business. It is because currently, Instagram is a social media that is very popular among young people and adults. The promotion strategy is the company's activity to promote sales by diverting a convincing communication to buyers [2].

Previous research stated there was an increased potential for social marketers to use the internet for promotion [3]. Promotions using the internet have been widely applied by businesses because they have time and visual effectiveness in conveying information and products to consumers. Social media promotion is the use of social system promotion, weblog promotion, and more, this is the latest breakthrough in promotion [4]. The social system on Instagram is to have followers and follow accounts on Instagram. Through this system, they can communicate from sending messages, liking, and commenting on posts. To have followers, we have to present something that can be an attraction for potential customers. 


\section{International Journal of Research and Applied Technology}

1(1)(2021) 97-102

Journal homepage: https://ojs.unikom.ac.id/index.php/injuratech

Attracting the attention of consumers to buy products is necessary using the creativity coupled with different innovations than other business actors to compete. Creating innovation can be started from creative content, where the content can convey the message of the business to potential consumers with packaging that is easy to understand and unique. Content strategies for each social engagement platform require unique but complementary strategies [5]. Unique content can be seen from the visual display and the message conveyed can reach the point of connectivity between consumers and businesses in promoting the product. The connection is being able to convey the message content precisely from what is planned by the business actor. The message strategy not only aims to merge information that was previously thought to be unrelated but also helps create innovative connections and relationships between individuals [6]. The success of a business does not only focus on creativity but also innovation but must be complemented by marketing strategies on social media. Entrepreneurs are required to have mastered social media marketing to make an impact on consumers and be successful in building a business [7]. It is because being a successful entrepreneur must have a complete package from the concept plan to its execution.

Indonesia has many Instagram users with high usage who can use Instagram until five to ten times or more in a day. This time is used to control $72 \%$. Besides, the most interesting thing is $75 \%$ revealed they want to browse through the vendor account on Instagram [8]. The purpose of this study is to determine the impact of social media content as a Consumer Interest Withdrawal Strategy. The method used in this study is a qualitative method by collecting data descriptively, namely by analyzing several online shops on the Instagram application.

\section{Method}

This research used a qualitative and scientific method. The qualitative method is research used to discuss and analyze phenomena, events, social activities, attitudes, beliefs, perceptions, and individuals. The scientific method means that research activities are based on scientific characteristics namely rational, empirical, and systematic. The data sources in this study are secondary data obtained indirectly from the source but using written sources such as book sources, journals, and documents from related parties regarding Instagram content, which is a strategy of attracting consumer interest. The documentation technique is a data collection technique in this study. The documentation method is information that comes from important records from institutions or organizations and individuals.

\section{Results and Discussion}

\subsection{Marketing}

Marketing is the activity of approaching to the public to provide information about related products to be marketed. Previous research said that marketing is a social process where there are individuals and groups, to get what they need and want by creating, offering, and freely exchanging valuable products with other parties [9]. In this case, the Hajarostore Instagram account does marketing by introducing products with the theme of Islamic religion, where the marketing target of the account is largely Muslim.

\subsection{Promotion}

Promotion is an activity to introduce products or services to get the attention and value of potential customers who aim to make the things offered can be sold. The 
importance of sales promotion is because consumer packaged goods companies allocate more than $50 \%$ of their marketing budget and $1 \%$ of their income for sales promotions [10]. One of the promotions conducted by Hajarostore is to use the Instagram platform as a media liaison with potential customers. According to Databoks sourced from We Are Social in January 2018, Indonesia is the third-largest country with 53 million active Instagram users, as of January 2018 (Figure 1).

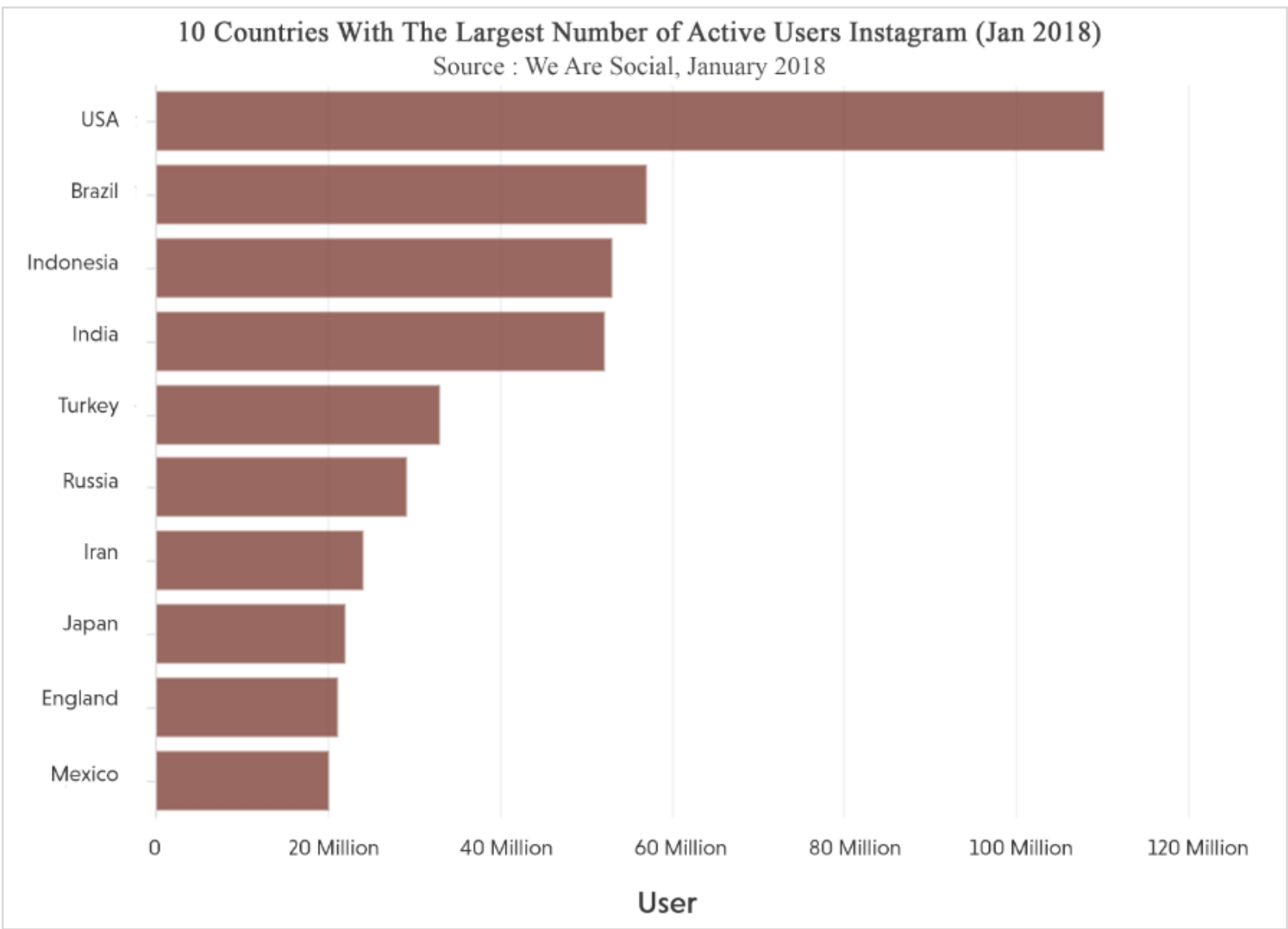

Figure 1. Databoks survey results regarding Instagram Active Users (We Are Social: Januari 2018)

This provides benefits for both consumers and producers. It is because producers can minimize spending on promotions and for consumers to be able to access information on products or services without having to come to the producer. Therefore, previous research suggested producers implement social media as a means of promoting their products because social media is a valuable marketing medium in reaching young market segments in a more agile and efficient manner [11].

\subsection{Withdrawal of Buying Interest}

Buying interest is a consumer's plan to buy a product or service based on the wants or needs of their feelings. It can be said that buying interest is a mental statement from the consumer that gives rise to a plan to purchase certain products or services. Many studies adopt an approach to identifying and testing factors that distinguish the level of ethical 


\section{International Journal of Research and Applied Technology}

1(1)(2021) 97-102

Journal homepage: https://ojs.unikom.ac.id/index.php/injuratech

or environmental actions in consumers [12]. Previous research said there are four indicators that can identify consumer-buying interest, namely:

- Transactional interest that is a person's tendency to buy products.

- Interest referrals, namely the tendency of individuals to recommend products or services to other individuals.

- Preferential interest, which is an interest that explains the character of an individual who has an important preference for the product or service. If something happens to the preference of the product, then it can be replaced with another preference.

- Explorative interest exposes the character of individuals who always explore explanations about the product or service they want and explore information to support the positive characteristics of the product or service [13]. One of the reasons his consumers buy the product offered is because they feel there is an emotional closeness to the theme taken by the seller that is related to Muslims. From these statements, it can be said that Hajarostore consumers have a type of preferential interest. Content is an idea that produces information. Content can be delivered through many things, one of them through social media. It must have a sale value to attract someone's interest not only the sale value but also the consistency that must be maintained for the selling agents. Previous research stated content is said to be of general value if:

- Can generate interest, involve, also inform and educate customers

- Reveal all values that identify the company in terms of uniqueness, consistency, quality and relevance.

- Being proactive, which is able to evolve over time [14].

Hajarostore applies the concept of content with a Muslim nuanced theme. From the photo used to the description of the photo. The following is an example of the content displayed by Hajarostore (see Figure 2).

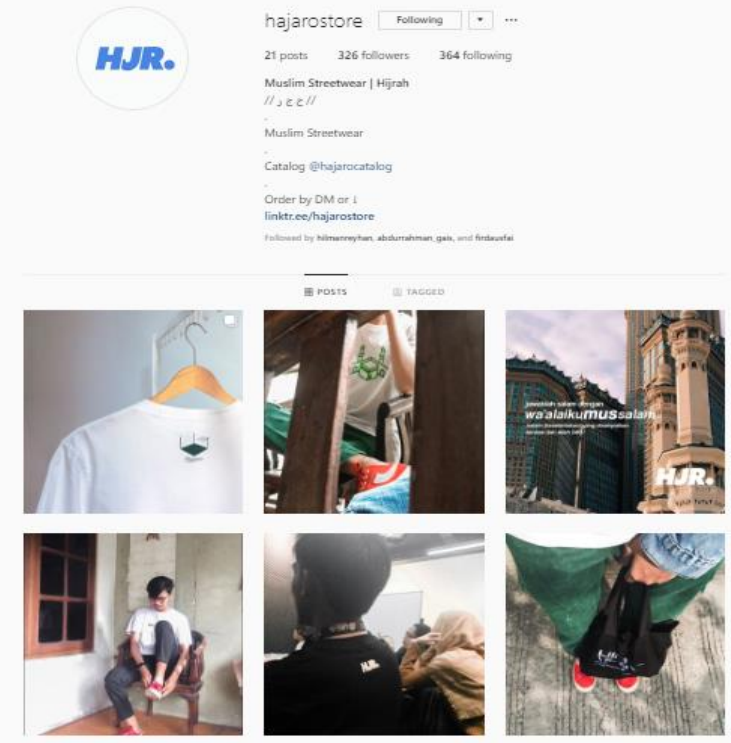

Figure 2. Display Instagram of Hajarostore photo content 


\title{
International Journal of Research and Applied Technology
}

\author{
1(1)(2021) 97-102
}

Journal homepage: https:/ /ojs.unikom.ac.id/index.php/injuratech

Figure 2 shows that from the preparation of Hajarostore photo content it is displayed Muslim attributes not only in the preparation of photo content but also the content in the description of the photo description. Where these contents are used as a strategy in attracting consumer interest specifically for Muslim consumers (Figure 3).
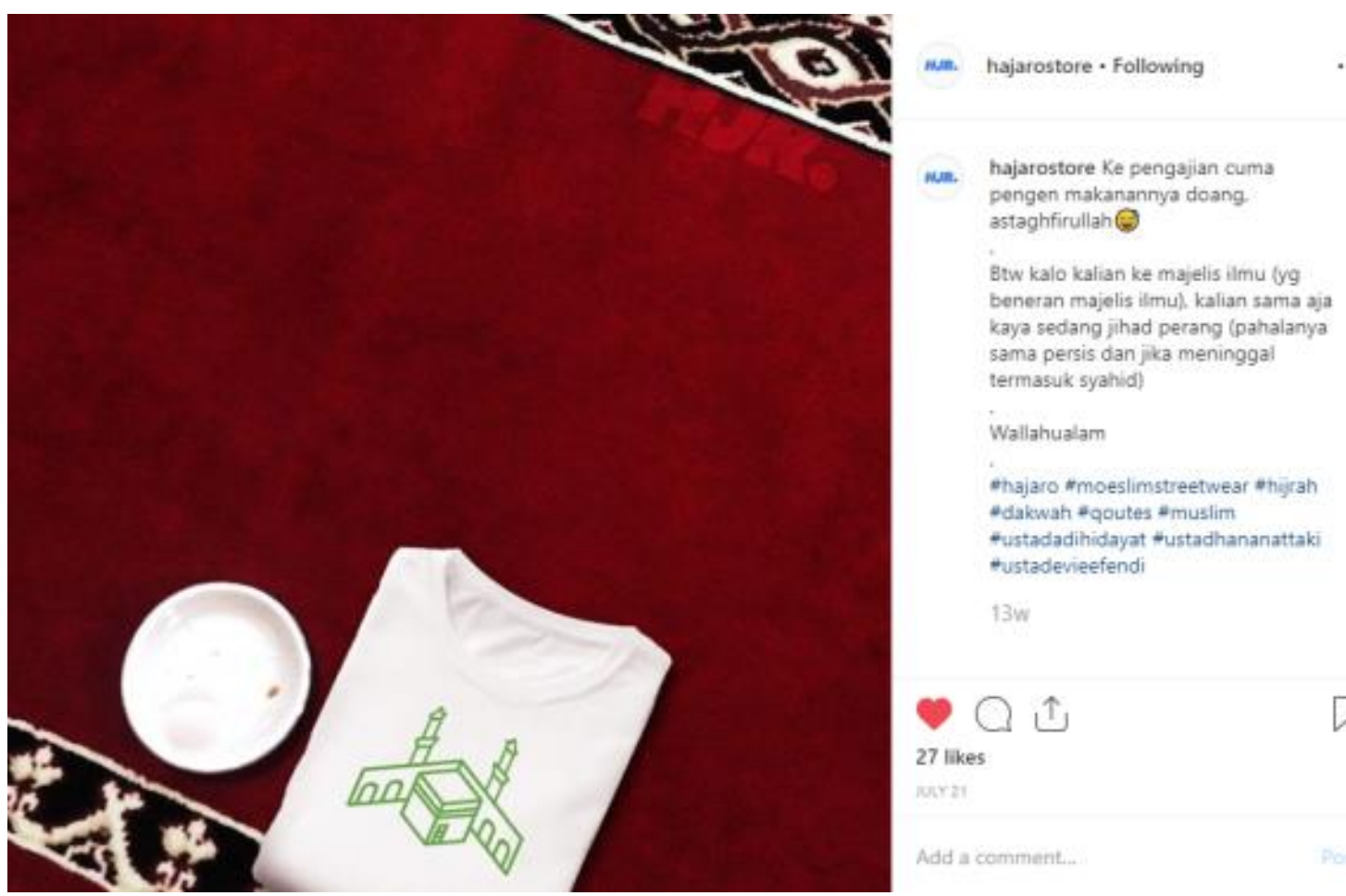

Figure 3. Display content in the form of photos and description captions Hajarostore

\section{Conclusion}

The development of technology provides a place for business people to start and continue business from marketing and promotion to make consumers have a more efficient interest. Instagram is a social media platform that is being used a lot. Business operators utilize these conditions to market their products and services. We have to market the products or services offered to make it more interesting, namely the concept of compiling interesting and consistent content. Therefore, business people can attract the interest of potential customers.

\section{Acknowledgement}

We would like to thank the Rector of Universitas Komputer Indonesia Prof. Dr. Ir. Eddy Soeryanto Soegoto, M.T, for helping us in providing the material and information so that this journal can be completed well. 


\section{International Journal of Research and Applied Technology}

1(1)(2021) 97-102

Journal homepage: https://ojs.unikom.ac.id/index.php/injuratech

\section{References}

[1] Soeryanto, Eddy Soegoto. 2009. Entrepreneurship Menjadi Pebisnis Ulung. Bandung: Elex Media Komputindo.

[2] Stephen, A. T. 2016. The role of digital and social media marketing in consumer behavior. Current Opinion in Psychology, 10, pp.17-21.

[3] Sajid SI 2016 Social Media and Its Role in Marketing. Bus Eco J 7: 203.

[4] Thackeray, R., Neiger, B. L., Hanson, C. L., \& McKenzie, J. F. 2008. Enhancing Promotional Strategies Within Social Marketing Programs: Use of Web 2.0 Social Media. Health Promotion Practice.

[5] Kristie Vanauken.. 2014. Practice papers: Using social media to improve customer engagement and promote products and services. Henry Stewart Publications 1750-1946 Airport Management, 9(2), pp. 109-117 Winter

[6] Ashley, C., \& Tuten, T. 2014. Creative Strategies in Social Media Marketing: An Exploratory Study of Branded Social Content and Consumer Engagement. Psychology \& Marketing, 32(1), pp. 15-27.

[7] Asst. Prof. Dr. Mustafa Boz. 2011. Successful Promotion Strategy In Destination Tourism Marketing Through Social Media; Queensland, Australia Case. Duygu Unal.

[8] Lee, E., Lee, J. A., Moon, J. H., \& Sung, Y. 2015. Pictures speak louder than words: Motivations for using Instagram. Cyberpsychology, Behavior, and Social Networking, 18(9), pp.552-556.

[9] Earley, M. A. 2014. A synthesis of the literature on research methods education. Teaching in Higher Education, 19(3), pp. 242-253.

[10] Hutasuhut, S., \& Wirawan, I. P. 2019. Socio-Economic and Parental Attention toward Learning Achievement with Mediation of Motivation to Learn. Tadris: Jurnal Keguruan dan Ilmu Tarbiyah, 4(2), pp. 189-202.

[11] Challagalla, G., Murtha, B. R., \& Jaworski, B. 2014. Marketing doctrine: a principles-based approach to guiding marketing decision making in firms. Journal of Marketing, 78(4),pp. 4-20.

[12] Turner, L., Leider, J., Piekarz-Porter, E., Schwartz, M. B., Merlo, C., Brener, N., \& Chriqui, J. F. 2018. State laws are associated with school lunch duration and promotion practices. Journal of the Academy of Nutrition and Dietetics, 118(3), pp.455-463.

[13] Balakrishnan, B. K., Dahnil, M. I., \& Yi, W. J. 2014. The impact of social media marketing medium toward purchase intention and brand loyalty among generation Y. ProcediaSocial and Behavioral Sciences, 148, pp.177-185.

[14] Tregear, A., \& Ness, M. 2005. Discriminant Analysis of Consumer Interest in Buying Locally Produced Foods. Journal of Marketing Management, 21(1-2), pp.19-35. 